\title{
Board Composition And Accountability Of Non-Profit Organizations
}

\author{
Roshayani Arshad, Accounting Research Institute, Universiti Teknologi MARA, Malaysia \\ Noorbijan Abu Bakar, Accounting Research Institute, Universiti Teknologi MARA, Malaysia \\ Nuraadhiah Yusoff Thani, Accounting Research Institute, Universiti Teknologi MARA, Malaysia \\ Normah Omar, Accounting Research Institute, Universiti Teknologi MARA, Malaysia
}

\begin{abstract}
Non-profit organizations (NPOs) are generally subjected to less stringent regulatory requirements than for-profit organizations. As such, NPOs are generally reluctant to share more comprehensive information with the various stakeholders and may not recognize the need for accountability. The purpose of this study is to examine the influence of board composition on the level of accountability for NPOs in Malaysia. Board composition and the level of accountability are obtained from the content analysis of annual reports of 234 societies registered with Registrar of Societies in Malaysia for the financial period 2010. The level of accountability (ADI) examined is based on two main components, transparency and compliance while board composition examined in this study consists of board size, board professionalism and board members with political connections. Results of this study provide evidence that the overall level of accountability is low. This infers that more comprehensive regulatory requirements or at the very least, the existence of best practices with regards to accountability can be a useful mechanism in enhancing the accountability of NPOs. In addition, the results also highlight that an optimum mix of board members matters in ensuring efficient resource strategy and consequently enhance the level of accountability in NPOs. Overall, the findings in this study provide useful information to regulators in their continuous efforts to improve accountability in the non-profit sector. This in turn can enhance the credibility and sustainability of the NPOs.
\end{abstract}

Keywords: Non-profit Organizations; Accountability; Board Composition; Transparency; Compliance

\section{INTRODUCTION}

on-profit organizations (NPOs) are generally defined as associations, charities, and other voluntary
organizations formed to further cultural, religious or public service objectives (Bottiglieri et al.,
2011). Overall, such organizations exist to provide benefits to members of the public. These organizations are supported by public donations as well as from other revenue generating activities such as obtaining grants from funders, contracting with government to provide services and charging for services rendered. It is reasonable for the donors to expect that the NPOs to be trustworthy in handling the funds they receive and also in the use of these funds. Managing donations and other primary decisions in NPOs are the responsibility of the board of trustees. This board is equivalent to the corporate board of directors. While board of directors in NPOs are expected to focus on social objectives in order to make their organizations more attractive to donors, Brickley et al. (2010) argue that such boards may not be an effective mechanism in constraining insiders from expropriating donations and other organizational resources. For example, in the recent case involving American Red Cross during the aftermath of Hurricane Katrina, the organization was criticized for raising money more than necessary and not spending it properly. Consequently, members of the public became reluctant to donate funds while the donors increasingly wanted the money they donated to be properly allocated and reported. In other words, in order to ensure continued support from donors as well as other stakeholders, it is important that NPOs discharge their actions accountably. 
One important element of accountability is transparency (e.g. Behn et al., 2010 and Burger \& Owens, 2010). Transparency is paramount as it reduces information asymmetries between NPOs and their stakeholders and in turn increases the ability of these stakeholders to oversee the activities of NPOs. This infers that transparency is not only limited to the publication of information in the annual reports but also information regarding the governance practices of the NPOs. In this regard, governance practices refer to compliance with regulatory requirements and recommendations in line with its public service objectives and also provide accurate, complete and informative information in the annual reports (Behn et al., 2010). However, as NPOs are generally subjected to less stringent regulatory requirements, the information reported by the NPOs can be insufficient or misrepresented for effective monitoring of their activities. Consistent with this argument, Burger \& Owen (2010) find that many NPOs that claimed to be transparent either failed to provide information or provide inaccurate information. While provision of information by NPOs is important in mitigating information asymmetry and enhancing accountability, there is lack of empirical evidence regarding the factors that influence the extent of disclosure and reporting practices of NPO, particularly in developing countries (Atan et al., 2012; Othman \& Ali, 2012).

This study aims to fill this gap by examining the influence of board composition on the level of accountability in NPOs. The level of accountability examined is based on two main components, transparency and compliance. Such examination is expected to provide some insight into the potential motivations for transparency and accountability among the NPOs and consequently contributes to the deliberations of enhancing accountability of NPOs by various regulatory authorities.

This paper will proceed by outlining the background of NPOs in Malaysia. It will then review the literature on the relationships between accountability, and respectively, resource dependence theory and board composition, from which hypotheses will be developed. Finally, this paper will proceed to the empirical stage of variable measurement, sampling, data analysis, discussion of results, limitations and suggestions for future research.

\section{NPOs IN MALAYSIA}

In Malaysia, NPOs comprised of organizations that are either charitable organizations or societies. NPOs with revenue of more than RM1 million can be registered as companies limited by guarantee and must be registered with the Companies Commission of Malaysia (CCM) and is held accountable by the Companies Act of 1965. For NPOs with revenue less than RM1 million, they must be registered with the Registry of Societies Malaysia (ROS), within the Ministry of Home Affairs, and are held accountable by the Societies Act of 1966.

NPOs registered under the Companies Act or Societies Act may apply for tax exemption under the Income Tax Act 1967. The Inland Revenue Board stipulates two conditions that registered institutions must comply with in order to qualify for tax exemption. These conditions are: (1) it must be established in Malaysia for charitable purposes only and (2) the organization must spend at least $50 \%$ (or such percentage as may be determined by the Director General) of its income including donation received in the previous year for the activities which were approved to achieve its objectives for the basis period for a year of assessment. In relation to disclosure and reporting requirements, there is no specific accounting standard for the NPOs. Nevertheless, NPOs are encouraged to comply with the International Financial Reporting Standards issued by International Accounting Standard Board and adopted by the Malaysian Accounting Standard Board or reporting standards applicable for private entities in the preparation and presentation of their financial statements. NPOs registered with ROS are required to submit Form 9 that consists of the statement of receipts and payments of the last financial year, together with a balance sheet showing the financial position of the last financial year to the ROS within sixty days after holding its annual general meeting. Other statements such as cash flow statement, statement of changes in general fund and notes, comprising a summary of significant accounting policies and other explanatory notes are not required by the ROS. The overall disclosure and reporting requirements of NPOs in Malaysia reflect a minimum regulatory requirement environment. 


\section{LITERATURE REVIEW AND GENERATION OF HYPOTHESES, RESOURCE DEPENDENCE THEORY, BOARD COMPOSITION AND ACCOUNTABILITY}

NPOs are characterized by their dependence on public donations, government fundings and fees. According to resource dependence theory (RDT), an organization operating in this environment will survive if they can manage the flow of resources and reduces the uncertainty in their environment (Pfeffer \& Salancik, 1978). In addition, RDT contends that board of directors enables organizations to minimize dependence on resources or gain resources. Prior empirical studies provide evidence that board of directors is associated with successful resource dependence strategy (e.g. Pfeffer, 1973 and Sanders and Carpenter, 1998). More recent studies suggest that type of directors on the board is associated with different benefits to the organizations. For example, board members from financial institutions are more likely to affect the financing obtained by organizations (Luoma and Goodstein, 1999) and stakeholder directors are more likely to improve corporate social performance (Johnson and Greening, 1999). Hence, these studies highlight that board composition matters in ensuring successful resource strategy. This study focuses on three types of board composition: board size, board professionalism and members with political connections. In addition, this study focuses on the relationships between various board members and the level of accountability of NPOs.

\section{BOARD SIZE AND ACCOUNTABILITY}

The RDT literature suggests that board size in NPOs is likely to vary with the amount of complexity and uncertainty in the external environment (Boyd, 1990; Dess \& Beard, 1984; Pfeffer, 1972, 1973; Pfeffer \& Salancik, 1978). For example, more board members with link to important resources in the external environment will be recruited on the boards of NPOs. This suggests that the size of the board in NPOs is likely to be fairly large.

NPOs dependence on public donations, government fundings and other types of funds reflect that NPOs are accountable to multiple stakeholders. The increasing number of NPOs indicates that the competition for funds is constantly growing. Hence, it is paramount that an NPO is seen as accountable in order to maintain the trust of the various stakeholders (Doncaster \& Hughes, 1996). Loss of trust can potentially reduce an organization's ability to attract or maintain donors, to communicate with other organizations and reputation as a legitimate NPO. This infers that boards of NPOs need to be concerned with the issue of accountability to their various stakeholders. As accountability means different things to different stakeholders (Doyle, 2005), it is only possible for the boards to fulfill their obligations in ensuring that the organization is accountable to the multiple stakeholders if there are sufficient members on the board. Larger board size is more likely to be comprised of members with various experience, expertise, knowledge and experience. Based on this reasoning, the following hypothesis is developed:

H1: The size of the board is significantly positively related to the level of accountability.

\section{BOARD PROFESSIONALISM AND ACCOUNTABILITY}

The previous discussion highlights that board functions as a resource for the NPOs. Brown (2005) suggests that board capital consists of experience, expertise and reputation. The human capital of the board members can facilitate them to guide the strategic direction of the NPOs. Mwenja \& Lewis (2009) argue that these board members are an important resource to the NPOs as board's role in the strategic direction of an organization is a significant contribution to the long-term survival of the NPOs. Hence, it is expected that board members with professional backgrounds are more capable to assist the NPOs in analyzing and understanding the complex environment under which the NPOs operate. One aspect of such complexity is related to managing organizational responsiveness to the needs of multiple stakeholders that the NPOs are accountable to. In order to ensure long-term survival of the organization, board members need to manage the relationships with the various stakeholders (Rehli \& Jager, 2011). Based on this argument, it is expected that board members with professional backgrounds are more capable to implement strategic plans that are perceived to be accountable to a wide range of stakeholders. In addition to their experience and expertise, board members with professional backgrounds are expected to be concerned with maintaining and enhancing their reputation. The reputation of professionally qualified board members is associated with their membership in the professional bodies. In general, they are obliged to comply with their professional commitments and are more likely to direct their organization to engage in activities considered as accountable by the 
various stakeholders (Chalmers \& Godfrey, 2004). Hence, the following hypothesis is developed:

H2: The percentage of board members with professional affiliations is significantly positively related to the level of accountability.

\section{POLITICAL CONNECTIONS AND ACCOUNTABILITY}

As the board functions as a resource for the NPOs (Pfeffer \& Salancik, 1978), the board provides an important link between the various stakeholders and the organisation. This in turn suggests that it is important that the organization develops and maintains healthy relationships with the various stakeholders (Mwenja \& Lewis, 2009). Mwenja \& Lewis (2009) argue that through these relationships or external social networks, the organization will be able to expand the organization's donor base and consequently bring in resources into the organization. Past studies provide evidence that board members with political connections are associated with preferential access to funds (e.g. Claessons et al., 2008 and Faccio \& Masulis, 2006). It is possible that through their existing and wide external social networks and reputations, they can exert more influence in attracting new donors from a wide range of stakeholders. Concurrently, their external network ties, including various governmental agencies and regulatory authorities also increase the board members involvement in strategic decisions (Carpenter \& Westphal, 2001). They are expected to be more supportive of calls for accountability issues in NPOs promoted by these bodies. This infers that these board members will be able to make more meaningful contributions in enhancing the accountability of NPOs. Consequently, this is expected to result in the flow of funds to the NPOs. Following this argument, the following hypothesis is developed:

H3: The percentage of board members with political connections is significantly positively related to the level of accountability.

\section{METHODOLOGY}

\section{Sample And Data Collection}

The sample consists of 234 societies registered with the Registrar of Societies (ROS) for the financial year 2010. The research approach involves the content analysis of societies' annual reports. Content analysis has been widely employed in prior studies to measure voluntary and mandatory disclosures in annual reports (e.g. Hackston \& Milne, 1996; O’Donovan, 2002; Clemens \& Douglas et al., 2006).

\section{Level Of Accountability}

The level of accountability (ADI) in this study is measured using a self-constructed index. In general, accountability refers to tools or techniques used to achieve accountability (Ebrahim, 2003). The identification of items to be included in the index is guided by the review of prior studies relevant to accountability of NPOs (e.g. Ebrahim, 2010 and Ebrahim \& Weisband, 2007), mandatory disclosures as required by the Societies Act 1966 and recommended practices by various regulatory authorities. Recommended practices in relation to governance and accountability of NPOs are based on Financial Action Task Force (FATF) report, Asia Pacific Group (APG) Mutual Evaluation 2007, APG Typology 2011. FATF is a policy-making body established in 1989 that is responsible to generate political will in the development of legislative and political reforms in the areas of anti-money laundering and terrorism financing for all sectors, including non-profit sector. Compliance with recommended practices by FATF in the Asia Pacific region is assessed by APG. APG will assess the compliant status of each member country. Malaysia became member of the APG on 31 May 2000 and as a consequent, is required to implement and comply with the FATF's recommendations with regards to anti-money laundering and terrorism financing. Failure to comply can cause a member country to be blacklisted and subject to various sanctions e.g. economic sanction, trade restriction, higher level of scrutiny, etc.

Based on the review of relevant literatures and recommended practices, a list of items to be included under accountability practices is identified. This is followed by discussions with several officials from ROS in order to get insights into the types of information considered as relevant practices on accountability for the NPOs. The level of 
ADI is measured by comparing the contents of each annual report to the items in the index and coded as " 1 " if the item is disclosed, " 2 " if the item disclosed contained quantitative or qualitative information and " 0 " if not disclosed. As in previous studies, disclosure item considered as not applicable to a company will not be penalized. Further, in assessing the applicability of a particular item, the entire annual report will be read to be reasonably certain that no similar information can be found in any part of the annual report before a judgement is made on this matter.

For each society, the ADI index score is calculated as a ratio of the actual score awarded to the company divided by the maximum potential score awarded to that company. The ADI index used for each company in order to measure the level of ADI is calculated as follows:

$A D I_{j}=\frac{\sum_{i=2}^{n_{j}} X_{\mathrm{i} j}}{n_{j}}$

Where $n_{j}=$ number of items expected for $j^{\text {th }}$ society, $n_{j}$ is $\leq 53$,

$X_{i j}=1$ if $i^{\text {th }}$ item disclosed, 2 if $i^{\text {th }}$ item disclosed includes quantitative or qualitative information and 0 if $i$ th item not disclosed,

So that $\quad 0 \leq I_{j} \geq 1$

The total score $\mathrm{ADI}_{j}$ represents the number of points awarded to society $j$ and it is an ordinal measure of the level of ADI for each company. The score is additive and unweighted. The use of unweighted index eliminates the assignment of weights to reflect the importance of certain types of information (Chow \& Wong-Boren, 1987). Hence, it increases the objectivity of the index as a measure of the extent of ADI disclosure (Gray et al., 1995). Further, Chow \& Wong-Boren (1987) suggest that the use of weighted or unweighted disclosure index is interchangeable because they find almost equivalent results using either one of the index.

\section{Measurement Of Variables}

There are three independent variables in this study, board size, board members with professional affiliations and board members with political connections. In addition to the identified independent variables, this study also includes one organisational characteristic identified in prior research as a determinant of management disclosure decision (e.g. Gray et al., 1995; Haniffa \& Cooke, 2005) as control variable. This variable is size. The definition and measurement of variables used in this study are listed in Table 1.

Table 1: Definition and Measurement of Variables

\begin{tabular}{|l|l|l|}
\hline \multicolumn{1}{|c|}{$\begin{array}{c}\text { Variable } \\
\text { Acronym }\end{array}$} & \multicolumn{1}{c|}{ Definition } & \multicolumn{1}{c|}{ Measurement } \\
\hline ADI & Level of Accountability & $\bullet$ Self constructed accountability index. \\
\hline B_SIZE & Board size & $\bullet$ Total number of board members. \\
\hline B_PROF & $\begin{array}{l}\text { Board members with professional } \\
\text { affiliations }\end{array}$ & $\begin{array}{l}\text { Percentage of board members with professional affilitations } \\
\text { to total number of board members. } \\
\text { Professional affiliation refers to members with professions in } \\
\text { areas such as accounting, management, engineering, } \\
\text { architecture and medical. }\end{array}$ \\
\hline B_POL & Board members with political connections & $\begin{array}{l}\text { Percentage of board members with political connections to } \\
\text { total number of board members. } \\
\text { Political connections refer to members being conferred } \\
\text { awards by the Government of Malaysia. For example, board } \\
\text { members with Dato', Tan Sri and Datuk Paduka. }\end{array}$ \\
\hline SIZE & Size of society & \begin{tabular}{l} 
Total revenues \\
\hline
\end{tabular} \\
\hline
\end{tabular}




\section{ANALYSIS AND RESULTS}

\section{Descriptive Statistics}

Table 2 presents the descriptive statistics on the dependent variable, ADI. The results of the descriptive statistics for continuous independent variables and control variable are presented in Table 3.

Table 2: Descriptive Statistics for Level of Accountability (ADI)

\begin{tabular}{|l|c|c|c|}
\hline & Minimum & Maximum & Mean \\
\hline ADI (\%) & 23 & 74 & 36 \\
\hline TRANS (\%) & 0 & 34 & 10 \\
\hline COMPL (\%) & 15 & 42 & 26 \\
\hline
\end{tabular}

Table 2 reported that ADI ranges from a minimum of $23 \%$ to $74 \%$. Further analysis of the two main components of ADI indicates that the level of transparency (TRANS) ranges from $0 \%$ to $34 \%$ while the level of compliance (COMPL) ranges from $15 \%$ to $42 \%$. While the maximum level of ADI is relatively high at $74 \%$, the results based on TRANS and COMPL indicate that societies are more concerned with compliance relative to disclosing more information in their annual reports.

Table 3: Descriptive Statistics for Independent and Control Variables

\begin{tabular}{|l|c|c|c|}
\hline & Minimum & Maximum & Mean \\
\hline B_SIZE & 4 & 33 & 13.51 \\
\hline B_PROF(\%) & 0 & 100 & 12 \\
\hline B_POL(\%) & 0 & 100 & 4 \\
\hline SIZE(RM'000) & 0.00 & $9,057.00$ & 300.17 \\
\hline
\end{tabular}

Table 3 reported that board of NPOs ranges from a minimum of 4 members to 33 members. Consistent with prior studies (Boyd, 1990; Dess \& Beard, 1984; Pfeffer, 1972, 1973; Pfeffer \& Salancik, 1978), this result indicates that some NPOs are fairly large in size. In relation to board composition, Table 3 reported that some NPOs have $100 \%$ members with professional affiliations while others have $100 \%$ board members with political connections. Finally, Table 3 reported that some NPOs are very small with no revenue to a fairly large size NPOs with maximum revenues of RM9.057million.

\section{MULTIVARIATE ANALYSIS}

In this study, linear multiple regression is used as the basis of analysis for testing H1 to H3. The hypothesized relationships are modeled as follows.

\section{Model 1:}

$\mathrm{ADI}=\beta_{0}+\beta_{1} \mathrm{~B} \_\mathrm{SIZE}+\beta_{2} \mathrm{~B} \_\mathrm{PROF}+\beta_{3} \mathrm{~B} \_\mathrm{POL}+\beta_{4} \mathrm{SIZE}+\varepsilon_{\mathrm{t}}$

Sub-analyses of the above relationships based on the two components of ADI, TRANS and COMPL are based on the following models:

Model 2:

TRANS $=\beta_{0}+\beta_{1}$ B_SIZE $+\beta_{2}$ B_PROF $+\beta_{3}$ B_POL $+\beta_{4} \operatorname{SIZE}+\varepsilon_{\mathrm{t}}$

Model 3:

$\mathrm{COMPL}=\beta_{0}+\beta_{1} \mathrm{~B} \_\mathrm{SIZE}+\beta_{2} \mathrm{~B} \_$PROF $+\beta_{3} \mathrm{~B} \_\mathrm{POL}+\beta_{4} \mathrm{SIZE}+\varepsilon_{\mathrm{t}}$ where variable definitions are given in Table 1 .

In the above regression models, multicollinearity was tested using the variance inflation factor and tolerance levels, and found to be well within the satisfactory range. The results of the regression analysis are presented in Table 4 and are now discussed in terms of tests of each of the hypotheses. 
Table 4: Multiple Regression Results for Factors Affecting the Level of Accountability

\begin{tabular}{|c|c|c|c|c|c|c|c|c|c|}
\hline Dependent Variable & \multicolumn{3}{|c|}{ ADI } & \multicolumn{3}{|c|}{ TRANS } & \multicolumn{3}{|c|}{ COMPL } \\
\hline $\mathrm{R}^{2}$ & \multicolumn{3}{|c|}{0.325} & \multicolumn{3}{|c|}{0.300} & \multicolumn{3}{|c|}{0.311} \\
\hline Adj. $\mathrm{R}^{2}$ & \multicolumn{3}{|c|}{0.307} & \multicolumn{3}{|c|}{0.281} & \multicolumn{3}{|c|}{0.293} \\
\hline $\mathrm{F}$ & \multicolumn{3}{|c|}{18.241} & \multicolumn{3}{|c|}{16.185} & \multicolumn{3}{|c|}{17.078} \\
\hline Sig & \multicolumn{3}{|c|}{0.000} & \multicolumn{3}{|c|}{0.000} & \multicolumn{3}{|c|}{0.000} \\
\hline Model & Beta & $\mathrm{t}$ & Sig. & Beta & $\mathrm{t}$ & Sig. & Beta & $\mathrm{t}$ & Sig. \\
\hline (Constant) & & -0.131 & 0.896 & & -0.044 & 0.965 & & -0.246 & 0.806 \\
\hline B_SIZE & 0.039 & 0.685 & 0.494 & 0.023 & 0.394 & 0.694 & 0.037 & 0.635 & 0.526 \\
\hline B_PROF & 0.091 & 1.581 & 0.115 & 0.132 & 2.245 & $0.026 * *$ & 0.043 & 0.741 & 0.460 \\
\hline B_POL & 0.168 & 2.845 & $0.005 * * *$ & 0.173 & 2.884 & $0.004 * * *$ & 0.161 & 2.705 & $0.007 * * *$ \\
\hline REV & 0.440 & 7.464 & $0.000 * * *$ & 0.315 & 5.248 & $\mathbf{0 . 0 0 0} * * *$ & 0.466 & 7.825 & $0.000 * * *$ \\
\hline
\end{tabular}

Coefficient for each variable is shown with $\mathrm{t}$ values in parentheses. * Significant at 10 per cent level (1-tailed test); ** Significant at 5 per cent level (1-tailed test); *** Significant at 1 per cent level (1-tailed test)

Results of the multiple regression analysis in Table 4 report that the adjusted $\mathrm{R}^{2}$ is 0.307 . H1 predicts that B_SIZE is significantly positively related to ADI. The results in Table 4 reveal an insignificant relationship. Further analyses also reveal that B_SIZE is not significantly related to the two main components of ADI, TRANS and COMPL. Hence, HI is rejected. These results indicate that B_SIZE is not significantly related to the overall extent of accountability. In addition, it also highlights that board composition instead of size matters in ensuring successful resource strategy. This is consistent with prior studies where type of directors on the board is associated with different benefits to the organizations (Luoma and Goodstein, 1999; Johnson and Greening, 1999). Hence, an optimum board composition instead of board size that matters in facilitating the enhancement of accountability in NPOs.

With regards to board members with professional affiliation, the results in Table 4 reveal that only one component of ADI, i.e TRANS is significantly related with B_PROF. Hence, H2 is partly accepted. H2 predicts that B_PROF are obliged to comply with their professional commitments and are more likely to direct their organization to engage in activities considered as accountable by the various stakeholders (Chalmers \& Godfrey, 2004). In this context, as there is a minimum reporting requirement in accordance with the Societies Act 1966, B_PROF is more concerned with the disclosure strategy of the NPOs. In contrast, lack of recommended best practices for accountability being promoted by regulatory bodies reduces B_PROF motivations to enhance the level of COMPL in NPOs. These arguments offer possible explanations on the insignificant relationships between B_PROF and the compliance element of ADI. In addition, it is also consistent with the argument by Bottiglieri et al. (2011) regarding the establishment of compulsory procedures and policies by the government or other relevant authorities for the NPOs as they are not able to efficiently regulate themselves.

Of the board composition, results in Table 4 reveal that B_POL is significantly related with ADI as well as the two components of ADI, TRANS and COMPL. Hence, H3 is accepted. These results suggest that B_POL is a valuable resource to NPOs. Consistent with prior studies, these board members are more likely to attract donors from a wide range of stakeholders through their wide external social networks and reputations (e.g. Claessons et al., 2008 and Faccio \& Masulis, 2006). Such network could include various governmental agencies and regulatory authorities that are involved in promoting accountability of NPOs. This in turn will influence B_POL to be actively involved in the strategic decisions with regards to the enhancement of accountability of their NPO.

\section{CONCLUSION AND LIMITATIONS}

This study examines the relationships between various board compositions and the level of accountability in NPOs. The significant positive relationships between some board compositions and ADI indicates that some characteristics of board members are important resources to the NPOs. For example, the significant positive relationships between B_POL and ADI indicate that board members with political connections can potentially enhance the accountability of NPOs through their external social networks. The insignificant relationships between B_SIZE and ADI highlights that an optimum mix of board members is paramount in ensuring efficient resource strategy and consequently enhance the level of accountability in NPOs. 
The significant relationships between B_PROF and only one component of ADI, that is TRANS, suggests that more comprehensive regulatory requirements or at the very least, the existence of best practices with regards to accountability can be a useful mechanisms in enhancing the accountability of NPOs. This is particularly important as there are many stakeholders who have contributed significant time, energy and money to the NPOs efforts are interested to know that their contributions are used efficiently (Behn et al., 2010). In summary, the findings in this study have practical implications to various regulatory authorities in their continuous efforts on improving the monitoring, transparency and accountability of the non-profit sector. This in turn can enhance the NPOs credibility to a wide range of stakeholders.

Finally, there are some limitations in this study. First, this study focuses only on the level of accountability based on information disclosed in annual reports of the NPOs. Future research may consider the use of questionnaires sent to board members or members of the NPOs in gauging the items considered as measurement for accountability of NPOs. Second, this study examined the influence of various board compositions on the level of accountability based on board members identified in the annual reports. Finally, this study focuses only on three types of board members. Future research may also consider the use of questionnaires or interviews with the broader types of board members in gauging their influence on the level of accountability as well as other issues related to accountability of NPOs. Despite these limitations, this study provides useful insights in understanding the relationships between various board compositions and the level of accountability of NPOs in a developing country environment.

\section{AUTHOR INFORMATION}

Roshayani Arshad is an Associate Professor at the Faculty of Accountancy, Universiti Teknologi MARA. She holds a PhD in accountancy from UiTM, Master of Accountancy from Glasgow University and is a graduate member of ACCA. She is currently the Head of Financial Reporting Research Centre and Research Fellow at the Accounting Research Institute and actively involved in various research projects. Her research interests include Financial Reporting, Corporate Disclosures, Corporate Social Responsibility, Reporting for Non-Profit Organizations and Corporate Governance. She has also written several books on financial accounting and reporting. E-mail: Roshayani@salam.uitm.edu.my (Corresponding author)

Noorbijan Abu Bakar is an Associate Professor at the Faculty of Accountancy, Universiti Teknologi MARA. She holds a Master in Professional Accounting from St. Louis University, USA, BSc Accounting from Southern Illinois University, USA and an Associate Member (ACIS) of ICSA UK. She is an active member of the Examination Committee of Malaysian Institute of Accountants (MIA) and is currently the Chairperson of Working Group Committee of MIA Qualifying Examination. Her research interests include Reporting for Non-Profit Organisations, Corporate Governance and Financial Reporting.

Nuraadhiah Yusoff Thani is currently a research assistant at the Accounting Research Institute (ARI). She is a final year student of Master of Accountancy at Universiti Teknologi MARA. Her current research interests include Governance and Non-profit Organizations.

Normah Omar is the Director of the Accounting Research Institute (ARI), which is one of Malaysia's six centres of excellence recognized and funded by the Ministry of Higher Education, Malaysia. Her research interest is in the area of forensic accounting and financial criminology. As a proponent of applied research, she has completed numerous collaborative research works with government agencies, professional bodies, regulators, non-government organizations and the corporate sectors in Malaysia. Currently, she is heading one of the Malaysian Institute of Integrity's (MII) collaborative research projects on Corporate Integrity Framework.

\section{REFERENCES}

1. Atan, R., Zaiton, S., \& Wah, Y.B. (2012). Quality of information by charity organisations and its relations with donations. Recent Advances in Business Administration. 118-123. 
2. Behn, B. K., DeVries, D. D., \& Lin, J. (2010). The determinants of transparency in nonprofit organizations: An exploratory study. Advances in Accounting, incorporating Advances in International Accounting, 26, 612. doi: 10.1016/j.adiac.2009.12.001

3. Bottiglieri, W. A., Kroleski, S. L., \& Conway, K. (2011). The Regulation of Non-Profit Organizations. Journal of Business \& Economics Research, 9(9), 51-60.

4. Boyd, B. (1990). Corporate linkages and organizational environment: A test of the resource dependence model. Strategic Management Journal, 11(6), 419-430.

5. Brickley, J. A., Horn, R. L. V., \& Wedig, G. J. (2010). Board composition and nonprofit conduct: Evidence from hospitals. Journal of Economic Behavior \& Organization, 76, 196-208 doi.10.1016/j.jebo.2010.06.008

6. Brown, W. A. (2005). Exploring the association between board and organizational performance in nonprofit organizations. Nonprofit Management and Leadership, 15(3), 317-339. doi: 10.1002/nml.71

7. Burger, R., \& Owens, T. (2010). Promoting Transparency in the NGO Sector: Examining the Availability and Reliability of Self-Reported Data. World Development, 38(9), 1263-1277. doi: 10.1016/j.worlddev.2009.12.018

8. Carpenter, M. A., \& Westphal, J. D. (2001). The Strategic Context of External Network ties: Examining the impact of director appointments on board involvement in strategic decision making. Academy of Management, 44(4), 639-660.

9. Chalmers, K., \& Godfrey, J. M. (2004). Reputation costs: the impetus for voluntary derivative financial instrument reporting. Accounting, Organizations and Society, 29(2), 95-125.

10. Chow, C. W., \& Wong-Boren, A. (1987). Voluntary Financial Disclosure by Mexican Corporations. The Accounting Review, 62(3), 533-541.

11. Claessens, S., Feijen, E., \& Laeven, L. (2008). Political connections and preferential access to finance: The role of campaign contributions. Journal of Financial Economics, 88(3), 554-580.

12. Clemens, B., \& Douglas, T. J. (2006). Does coercion drive firms to adopt 'voluntary' green initiatives? Relationships among coercion, superior firm resources, and voluntary green initiatives. Journal of Business Research 59, 483-491.

13. Dess, G. G., \& Beard, D. W. (1894). Dimension of Organizational Task Environments. Administrative Science Quarterly, 29(1), 52-73.

14. Doncaster, D., \& Hughes, J. (1996). Governance and control for not-for-profit organisations. The Philantropist, 13(3), 45-51.

15. Doyle, L. M. (2005). Nonprofit Board Accountability: A Literature Review and Critique. SPNA Review, $1(1)$.

16. Ebrahim, A. (2003). Accountability in Practice: Mechanisms for NGO. World Development, Vol. 31, No. 5, 813-829.

17. Ebrahim, A. (2010). The Many Faces of Nonprofit Accountability. Harvard Business School.

18. Ebrahim, A., \& Weisband, E. (2007). Global Accountabilities: Participation, Pluralism and Public Ethics. UK: Cambridge University Press.

19. Faccio, M., \& Masulis, R. W. (2006). Political Connections and Corporate Bailouts. The Journal of Finance, 61(6), 2597-2635.

20. Gray, R., Kouhy, R., \& Lavers, S. (1995). Corporate social and environmental reporting: a review of the literature and a longitudinal study of UK disclosure. Accounting, Auditing \& Accountability Journal, 8(2), 47-77. doi: 10.1108/09513579510146996

21. Hackston, D., \& Milne, M. J. (1996). Some determinants of social and environmental disclosures in New Zealand companies. Accounting, Auditing \& Accountability Journal, 9(1), 77-108. doi: $10.1108 / 09513579610109987$

22. Haniffa, R. M., \& Cooke, T. E. (2005). The impact of culture and governance on corporate social reporting. Journal of Accounting and Public Policy, 24(5), 391-430.

23. Johnson, R. A., \& Greening, D. W. (1999). The Effects of Corporate Governance and Instittutional Ownership Types on Corporate Social Performance. Academy of Management Journal, 42(5), 564-576.

24. Luoma, P., \& Goodstein, J. (1999). Stakeholders and Corporate Boards: institutional influences on board composition, Research Note. Academy of Management Journal, 42, 553-563.

25. Mwenja, D., \& Lewis, A. (2009). Exploring the impact of the board of directors on the performance of notfor-profit organizations. Business Strategy Series, 10(6), 359-365. doi: 0.1108/17515630911005646 
26. O'Donovan, G. (2002). Environmental disclosures in the annual report: Extending the applicability and predictive power of legitimacy theory. Accounting, Auditing \& Accountability Journal, 15(3), 344-371.

27. Othman, R., Ali, N. (2012). NPO, Internal Controls, and Supervision Mechanisms in a Developing Country. Voluntas, DOI 10.1007/s 11266-0012-9335-4.

28. Pfeffer, J. (1972). Size and composition of corporate boards of directors: The organisation and its environment. Administrative Science Quarterly, 17, 219-228.

29. Pfeffer, J. (1973). Size, Composition, and Function of Hospital Boards of Directors: A Study of Organization-Environment Linkage. Administrative Science Quarterly, 18(3), 349-364.

30. Pfeffer, J., \& Salancik, G. (1978). The External Control of Organisations, A Resource Dependence Perspective. New York: Harper and Row.

31. Rehli, F., \& Jager, U. P. (2011). The Governance of International Nongovernmental Organisations: How Funding and Volunteer Involvement Affect Board Nomination Modes and Stakeholder Representation in International Nongovernmental Organisations. Voluntas, 22, 587-612. doi: 10.1007/s11266-011-9197-1

32. Sanders, W. M. G., \& Carpenter, M. A. (1998). Internationalization and Firm Governance: The Roles of CEO Compensation, Top Team Composition, and Board Structure. The Academy of Management Journal, 41(2), 158-178. 